Innlegg på inntil 400 ord lastes opp i http://mc.manuscriptcentral.com/tidsskriftet.

Redaksjonen forbeholder seg retten til å foreta redaksjonelle endringer.

Forfattere av vitenskapelige artikler har automatisk tilsvarsrett (jf. Vancouver-gruppens regler).

\section{Upresist om transplantasjonskirurgi}

I Tidsskriftet nr. 5/2010 er forfatter og skribent Niels Chr. Geelmuyden gjestskribent (1). Han omtaler sin nefrologiske sykehistorie: medfødte cystenyrer og etter hvert utvikling av terminal nyresykdom og behov for dialyse. Hans kone er blitt utredet og akseptert som ledende giver av nyre til sin mann. Det er avtalt dato for innleggelse og for donoroperasjon og simultan nyretransplantasjon.

På grunn av uventet stor pågang av organer fra nylig avdøde med det resultat at både operasjonsavdelingen og sykeposten blir tungt belastet, blir avdelingen nødt til å utsette planlagte operasjoner, inkludert nyretransplantasjoner med donor fra levende givere.

Geelmuyden reagerer fordi hans kone som donor er blitt utsatt for store prøvelser i forbindelse med denne utsettelsen. Han beskriver at hun som donor ved denne utsettelsen av operasjonen «føler seg ved hjemsendelsen rubrisert som en rettighetsløs ansamling av blod og vev».

Jeg ønsker Geelmuyden alt det beste med nyretransplantasjonen og et ukomplisert forløp etter donoroperasjonen hos hans kone. Som tidligere transplantasjonskirurg og som en av dem som i lang tid hadde ansvar for donoroperasjonene $\mathrm{i}$ forbindelse med nyretransplantasjonene finner jeg imidlertid grunn til å reagere. Innen faget kirurgi må såkalte elektive operasjoner, altså planlagte operasjoner, alltid måtte finne seg i å vike for øyeblikkelig hjelpoperasjoner. Innen transplantasjonskirurgi er det nå engang slik at organer som er tatt ut fra nylig avdøde bør kobles til mottakerens blodførende organer innen 10-15 timer slik at nyrefunksjonen i det transplanterte organet ikke forringes. Et organ fra en nylig avdød person blir ikke funksjonelt bedre av å ligge flere timer ekstra i kjøleskapet.

Geelmuyden gjør et poeng av at avdelingen sies å ha utført en rekke transplantasjoner en helg like forrut «uten å forskyve noen av de planlagte operasjonene». Det er uvanlig å planlegge operasjoner i helgen. Et slikt utsagn vil bare forsterke inntrykket av at Geelmuyden ikke forstår driftslogistikken i en avdeling som både driver akutt øyeblikkelig hjelp og planlagt elektiv virksomhet. Han er kjent som en skribent som retter søkelyset og pennen mot urimelig- heter i samfunnet. Han setter ofte ting på spissen. Etter min erfaring står ting som er satt på spissen, ofte ustøtt.

\section{Arnt Jakobsen \\ Oslo}

\section{Litteratur}

1. Geelmuyden NC. Ved Rikets port. Tidsskr Nor Legeforen 2010; 130: 576 .

\section{Klassifikasjonssystemenes utilstrekkelighet}

I Tidsskriftet nr. 5/2010 angripes S.E. Gullestad for å bringe klassifikasjonssystemene ICD-10 og DSM-IV i miskreditt (1). Alv Dahl underslår at det er dype kløfter i synet på disse. Som kjent fester disse klassifikasjonssystemene i grove trekk diagnoser til symptomnivå og er dermed relevant for psykiateren som skal stille diagnoser.

Dette er i og for seg greit. Trekkes imidlertid individet inn som bærer av symptomene, får man en helt annen historie. I dette perspektivet vil enheten «psykisk sykdom» løse seg opp på et sett som klassifikasjonssystemene ikke kan gjøre rede for. Man mister blikk for det viktige grunnlaget; hvorfor individet «ytrer» seg slik og slik. I motsetning til hva Dahl synes å tro, har Gullestad arbeidet med klassifikasjonsproblemet i tidligere arbeider (2).

\section{Dag Pedersen \\ Nordås \\ Litteratur \\ 1. Dahl AA. Byggingen av det psykologiske huset i Oslo. Tidsskr Nor Legeforen 2010; 130: 526-7. \\ 2. Gullestad SE, Killingmo B. Underteksten. Oslo: Universitetsforlaget, 2009 \\ Utvidet nyfødtscreening er grundig vurdert}

Bjørn Hofmann reiser i en kronikk i Tidsskriftet nr. 3/2010 en rekke viktige og prinsipielle spørsmål knyttet til screeningprogram som har som mål å finne medfødt metabolsk sykdom (1). Screening for fenylketonuri (Føllings sykdom) er i dag forskriftsregulert, med hjemmel i bioteknologiloven. Ny kunnskap, og ikke minst ny teknologi, gjør det mulig å utvide nyfødtscreeningen til også å omfatte en rekke andre medfødte metabolske sykdommer. Helsedirektoratet har gjennomført en bred prosess for å vurdere om vi skal ta denne muligheten i bruk. For dette formål er det gjort en kunnskapsoppsummering ved Nasjonalt kunnskapssenter for helsetjenesten, og en bredt sammensatt arbeidsgruppe har vurdert spørsmålet om utvidet nyfødtscreening.

Bjørn Hofmann var medlem av dette utvalget. De spørsmål og problemstillinger han reiser i kronikken var alle kjent og ble grundig drøftet i utvalgets innstilling (2) I innstillingen var det et flertall som mente at et slikt tilbud skulle være nettopp et tilbud, basert på god og tilstrekkelig informasjon og med reell reservasjonsrett, men uten krav om skriftlig samtykke. Et mindretall i utvalget mente at det var gode argumenter for å gjøre slik screening obligatorisk av hensyn til barnets beste. Saken ble også, med utgangspunkt i utvalgets rapport, behandlet i Nasjonalt råd for kvalitet og prioritering i helsevesenet, der alle disse prinsipielle spørsmålene ble grundig debattert (3). Et stort flertall mente screeningen skulle gjøres, men med reservasjonsrett. Et mindretall foreslo også der obligatorisk screening. Etter dette har direktoratet behandlet saken og tilrådet et utvidet screeningprogram i tråd med utvalgets flertallsinnstilling.

Det er viktig at allmennheten er kjent med at de vanskelige problemstillingene som Bjørn Hofmann tar opp i sin kronikk har vært grundig vurdert av flere instanser som alle konkluderer med at utvidet nyfødtscreening likevel vil være medisinskfaglig, juridisk og etisk forsvarlig.

Saken ligger nå i Helse- og omsorgsdepartementet til avgjørelse.

\section{Hans Petter Aarseth}

Helsedirektoratet

\section{Litteratur}

1. Hofmann B. Nyfødtscreening - mer skjult tvang? Tidsskr Nor Legeforen 2010; 130: 291-3.

2. Helsedirektoratet. Anbefalinger vedrørende utvidet nyfødtscreening og screening av gravide for alloimmun trombocytopeni hos fosteret/nyfødte. www. helsedirektoratet.no/vp/multimedia/archive/ 00135/Anbefalinger_vedr_r_135109a.PDF (6.4.2010).

3. Nasjonalt råd for kvalitet og prioritering i helsetjenesten. Screening hos nyfødte - utvidelse av nåværende program? www.kvalitetogprioritering no/Saker/12366.cms (6.4.2010). 